\title{
The Optimization of the Number of Halal Auditor to Improve Halal Product Assurance in Indonesia (The Perspective of Law Number 33 of 2014 concerning Halal Product Guarantee) \\ DOI: https://doi.org/10.47175/rissj.v2i4.337
}

\section{${ }^{1,2}$ Faculty of Law, Universitas Muhammadiyah Sumatera Utara, Indonesia}

| Farid Wajdi ${ }^{1, *}$ | Cynthia Hadita ${ }^{2}$

*faridwajdi@umsu.ac.id

\begin{abstract}
The lack of quantity of halal auditors has implications for the less than optimal implementation of halal product guarantee in Indonesia, so it is necessary to compare with Brunei Darussalam in standardizing halal auditors. The research method used in this research is normative juridical. The results of the study indicate that halal auditors still need to optimize the quantity of halal auditors so that they are more optimal in halal and there will be an increase in halal product guarantee in Indonesia. Comparative with Brunei Darussalam, apart from an adequate quantity of halal auditors, there is also a code of ethics for trainee auditors (halal auditors), Indonesia needs to optimize the number of halal auditors and also have a code of ethics for halal auditors. So the results are more optimal and in accordance with Law of the Republic of Indonesia Number 33 Year 2014 on Halal Product Guarantee. KEYWORDS

Auditor; halal; optimization
\end{abstract}

\section{INTRODUCTION}

In the Halal Product Assurance Law Number 33 of 2014, (hereinafter referred to as the HIA Law) one of the requirements for a halal auditor is to have a certificate from the Indonesian Ulema Council (MUI). This certification is important to ensure the competence of auditors who are the spearhead in the halal certification process. MUI as an institution appointed by law then assigned the Professional Certification Agency of the MUI Food, Drug and Cosmetics Assessment Institute (LSP LPPOM MUI) to conduct certification in accordance with the scope of halal auditors that had been approved by BNSP. ${ }^{1}$ MUI has issued a competency test, 70 other halal inspection institutionswill be present. This can certainly help in the halal certification process. So far, only one party has issued halal certification, namely LPPOM MUI. ${ }^{2}$

Prior to the existence of Law Number 11 Year 2020 on Job Creation (hereinafter referred to as the Job Creation Law). Prospective halal auditors take professional certification at LSP-MUI. Because the cost of prospective halal auditors is relatively expensive, so the Job Creation Act answers one of the obstacles to producing many halal

\footnotetext{
${ }^{1}$ LPPOM MUI, "Sertifikasi Auditor Halal, Belum Ada Pendaftar Dari Luar," accessed at https://www.Halalmui.Org/Mui14/Main/Detail/Sertifikasi-Auditor-Halal-Belum-Ada-Pendaftar-Dari-Luar.

${ }^{2}$ Fabbiola Irawan, "Polemik Sertifikasi Halal, Ini Sederet Masalah Di Baliknya," accessed at https://Economy.Okezone.Com/Read/2019/12/18/320/2143594/Polemik-Sertifikasi-Halal-Ini-SederetMasalah-Di-Baliknya?Page=2.
} 
auditors. ${ }^{3}$ However, the quantity of halal auditors is still not optimal. Even though at this time, to become a halal auditor, it is enough to be appointed and dismissed by HIA.

During the Covid-19 pandemic, the selection of halal auditors was carried out online (on the network), the National Professional Certification Agency (BNSP) also ensured that LSPs were able to take mitigation and anticipation steps against fraud, errors, or other possible errors that might occur at the competency test during the assessment process. One of the mitigation efforts carried out is to require assessment participants to use two cameras on the video conferencing application used, namely facing and turning their backs on the participants. That way, the competency test can be seen 360 degrees and the Assessor can ensure that the room meets the requirements of the Competency Test Place. ${ }^{4}$

The issue of food and beverage products that are forbidden and dangerous is getting public attention. Instant food products, fast food, restaurants to market snacks are things that are prone to contamination by non-halal types of food, both in terms of ingredients and processes. $^{5}$

The number of training providers is very small, the cost standardization is still heavy. In addition, the parties involved in assisting the self-declaration process are not ready yet for Micro, Small, and Medium Enterprises (MSMEs). Therefore, synchronization of regulations, standardization of competence, development of halal science needs to be integrated through the curriculum in universities. More importantly, establishing halal economic integration with various parties needs to be pursued. This was conveyed in the Muhadatsah Forum of the Islamic Economic Community PP Expert Council which is expected to produce solutions that are solution and applicable for stakeholders. The Expert Council is expected to provide solutions to problems in the halal certification process so that it will also have an impact on strengthening the halal value chain in Indonesia. ${ }^{6}$

The lack of quantity of halal auditors has implications for the less than optimal implementation of halal product guarantees, the standardization regulated for people who can become halal auditors is an obstacle to the lack of halal auditors. Therefore, in this study, it will be compared with halal auditors in Indonesia and those in Brunei Darussalam in order to increase the number of halal auditors which will have an impact on increasing halal product guarantees which will certainly provide benefits to the community.

\section{RESEARCH METHODS}

The research method used is normative juridical law research which is carried out by examining library research. The approach used is a statutory and conceptual approach. ${ }^{7}$ This approach will be carried out with an in-depth study of the legislation and developing doctrines, especially those relating to the development of halal products. The type of study in this study is more descriptive in nature, which aims to describe or clearly describe things related to the object to be studied. ${ }^{8}$

\footnotetext{
${ }^{3}$ Republika, "BPHIA Keluhkan Tarif Sertifikasi Auditor Halal," accessed at https://www.Republika.Id/Posts/9340/BpHIA-Keluhkan-Tarif-Sertifikasi-Auditor-Halal\%C2\%A0.

${ }^{4}$ LPPOM MUI, "Menjadi Auditor Dan Penyelia Halal Tersertifikasi Saat Ini Mudah," accessed at https://www.halalmui.Org/Mui14/Main/Detail/Menjadi-Auditor-Dan-Penyelia-Halal-Tersertifikasi-Saat-IniMudah.

${ }^{5}$ Diana Candra Dewi, Rahasia Dibalik Makanan Yang Haram (Malang: UIN, 2007)

${ }^{6}$ Lida Puspaningtyas, "Dewan Pakar MES Sebut Kendala Jaminan Produk Halal," accessed at https://www.Republika.Co.Id/Berita/Qyzo2f370/Dewan-Pakar-Mes-Sebut-Kendala-Jaminan-Produk-Halal.

${ }^{7}$ Peter Mahmud Marzuki, Penelitian Hukum (Jakarta: Kencana, 2011).

${ }^{8}$ Soerjono Soekanto, Pengantar Penelitian Hukum (Jakarta: UI Press, 2012).
} 


\section{RESULTS AND DISCUSSION}

\section{Halal Auditor in the Law of the Republic of Indonesia Number 33 of 2014 concerning Halal Product Guarantee}

Muslims have certain characteristics, for example the issue of food safety not only materially, but also spiritually. The problem is that halal is closer between humans and their God. According to the Islamic perspective, the concept of consuming halal products is clearly recorded by Allah SWT. in the Qur'an (Surat al-Baqarah [2]: 172-173). Allah's message, outlining the philosophy and principles of halal in Islam. The main message is that the group of people who believe in the sight of Allah are those who maintain the halal and haram aspects in themselves. ${ }^{9}$

The state is committed to ensure that each inhabitant carries out his religion and conviction, counting in terms of satisfying the require for halal nourishment in understanding with the statement of faith of each Muslim. This can be in line with the rights of shoppers as directed in Law Number 8 of 1999 concerning Consumer Security Article 4, which incorporates the correct to consolation, security and security in expending products and or administrations, particularly for comfort (not causing hurt) questions and stresses in eating nourishments that are in agreement with their convictions. Each

maker must straightforwardly list the components of each nourishment produced to ensure the interface of shoppers. The commitment of trade on-screen characters to supply genuine, clear and honest data with respect to the conditions and ensures of goods and or administrations as well as to supply clarifications for utilize, repair and upkeep is additionally the correct of shoppers. The nonappearance of data or insufficient data will be exceptionally inconvenient to buyers. ${ }^{10}$

One of the basic and important needs for humans is food. Then in the matter of the food consumed, there are considerations that underlie the choice of food decisions. Sometimes in choosing food, taste is the main factor that drives this consumption behavior, then on the other hand it can be less concerned about the halal aspect. Muslim consumers guided by Islamic law should pay close attention to the halal aspect of the product and hope that every product consumed meets the halal criteria according to Islamic law. That in this aspect of halal contains spiritual values for a person, because of that Islamic law has set signs or provisions related to halal and haram in the study of food problems. The development of the times that occurred also influenced the food sector and public consumption. Within the matter of halal nourishment, it has been display within the community of nourishments that are labeled halal. Halal labeling and certification is something that really did not exist within the past, but presently it is considered pressing in building certainty, believe and certainty of the nourishment fabric expended, particularly for a Muslim, since Islam moreover directs nourishment issues with the presence of halal nourishment rules and directions. Basically, the command for halal labeling on food when viewed from the various interpretations that have been conveyed previously, explicitly does not exist. In the past, there was also no food with a halal label. However, considering

\footnotetext{
${ }^{9}$ Farid Wajdi, Jaminan Produk Halal di Indonesia (Jakarta: PT. RajaGrafindo Persada, 2019), pp. 33 \& 64.

${ }^{10}$ Siti Muslimah, "Label Halal Pada Produk Pangan Kemasan Dalam Perspektif Perlindungan Konsumen Muslim," in Yustisia 1, No. 2 (2012).
} 
the current situation and conditions, renewing the food sector with halal certification and labeling is very important. ${ }^{11}$

Referring to the constitution, Article 28E section (1) and Article 29 section (1) and passage (2) of the 1945 Structure (UUD 1945) mutatis mutandis, the State ensures the autonomy of each inhabitant to grasp their individual religions and to revere. agreeing to their religion and convictions. Moreover with the Indonesian Muslim populace, they have a sacred right to get lawful assurance against halal items in understanding with their devout convictions. In this manner, they ought to be given legitimate security in the form of a guarantee of halal food consumed and other products used. Regarding the institutional authority for halal product certification, based on Article 6 of the HIA Law which regulates the authority of HIAA, in letter (c), it is clearly stated that HIAA has the authority to issue and revoke Halal certificates. The article clearly states that only HIAA has the authority to issue and revoke Halal Certification and Halal Labels on a product. In terms of determining the halal product, it remains the authority of the MUI. Thus, even though there are changes in a number of substances of the HIA Law into the Job Creation Law, it does not change the authority of MUI in determining the halal products. ${ }^{12}$

The halal product is a obligatory necessity for each shopper, particularly Muslim customers. Be it items within the shape of nourishment, pharmaceutical or other customer products. As the amount of Muslim shoppers in Indonesia comes to 204.8 million individuals, the Indonesian market consequently gets to be a really huge Muslim customer advertise. In this manner, the guarantee of halal items is an imperative thing to urge the consideration of the state. As expressed within the Introduction to the 1945 Structure of the Republic of Indonesia (UUD 1945) that the State is obliged to secure the complete Indonesian country and the whole country of Indonesia and realize the common welfare. The Government of the Republic of Indonesia has made a positive reaction to halal issues, particularly those related to nourishment, medication and beauty care products. Be that as it may, these controls are made somewhat, conflictingly, appear to cover, and are not systemic so that actually they cannot be utilized as a solid lawful umbrella and can particularly tie the issue of halal item. As a tangible manifestation of the state's presence in protecting consumers from non-halal products, there are many laws that have long been used to regulate the circulation of halal products. ${ }^{13}$

The technical guarantee of halal products is then translated through a certification process. Previously, halal certification was voluntary, while the HIA Law was mandatory. Although according to Article 48 point 4A of the Job Creation Law, for MSME business actors, the obligation for halal certificates is based on the regulation of the business actor concerned (self-declaring). Therefore, all items that enter, circulate, and are exchanged within the domain of Indonesia must be certified halal. HIAA must be established no later than 3 (three) years from the promulgation of this Law. Currently, HIAA has been established, the implementing regulations of this Law must be stipulated no later than 2 (two) years from the promulgation of this Law. The obligation to be certified halal for Products circulating and traded in the territory of Indonesia shall come into effect 5 (five)

\footnotetext{
${ }^{11}$ Muhammad Syarif Hidayatullah, "Sertifikasi dan Labelisasi Halal Pada Makanan Dalam Perspektif Hukum Islam (Perspektif Ayat Ahkam)," in YUDISIA : Jurnal Pemikiran Hukum dan Hukum Islam 11, No. 2 (2020): 251.

${ }^{12}$ BPHIA Tegaskan Fatwa Penetapan Halal Tetap di MUI, accessed at https://www.halalmui.org/mui14/main/detail/bpHIA-tegaskan-fatwa-penetapan-halal-tetap-di-mui

${ }^{13}$ May Lim Charity, "Jaminan Produk Halal di Indonesia," Jurnal Legislasi Indonesia 14, no. 1 (2017): 99-108, accessed at https://e-jurnal.peraturan.go.id/index.php/jli/article/view/77
} 
years as of the promulgation of this Law. Before the obligation to be certified halal applies, the types of products that are certified halal are regulated in stages. ${ }^{14}$ After that, there is the existence of halal auditors who are appointed and dismissed by the Halal Examination Agency.

The procedure for obtaining halal certification at hotel restaurants issued by the Ministry of Religion, business actors must meet the requirements examined by HIAA, including data on business actors, names and types of business products, list of products and materials used, methods or processes for product processing and halal assurance system. After fulfilling the requirements, HIAA will examine the documents, then determine Halal Examination Agency that has been selected by the applicant, then Halal Examination Agency will carry out inspection and/or testing of halal product. ${ }^{15}$

The government is obliged to secure the open from devouring halal nourishment. The meaning of halal nourishment could be a sort of nourishment that does not contain haram components or fixings that are precluded for utilization by Muslims, both concerning nourishment crude materials, nourishment added substances, assistant materials and other assistant materials, counting nourishment fixings that are handled through hereditary designing and light forms. nourishment, and whose administration is carried out in understanding with the arrangements of Islamic devout law. Halal certificate and halal labeling are two diverse exercises but they are related to each other. ${ }^{16}$

The public interest or benefit must be something essential (necessary) and not luxury things. ${ }^{17}$ Regulations relating to halal auditors in positive law in Indonesia are regulated in Article 1 point 9 of the HIA Law which stipulates that "Halal auditors are people who have the ability to conduct product halal inspections". Article 1 number 6 of the HIA Law "Halal Product Assurance Agency, hereinafter abbreviated as HIAA, is an agency established by the Government to administer HIA". Article 6 of the HIA Law "In administering HIA, HIAA has the authority to: a. formulate and determine HIA policies; $b$. establish HIA norms, standards, procedures, and criteria; c. issue and revoke Halal Certificates and Halal Labels on Products; d. registering Halal Certificates on foreign Products; e. conduct socialization, education, and publication of Halal Products; f. carry out accreditation of HIA; g. registering Halal Auditors; h. to supervise HIA; i. conduct training for Halal Auditors; and J. cooperate with domestic and foreign institutions in the field of HIA implementation".

The duties of the Halal Auditor as referred to in Article 15 of the HIA Law are "Halal Auditors as referred to in Article 14 are tasked with: a. examine and review the materials used; b. inspect and review the Product processing process; c. inspect and review the slaughtering system; d. examine the location of the Product; e. researching equipment, production room, and storage; f. examine the distribution and presentation of Products; $g$.

\footnotetext{
${ }^{14}$ Asep Syarifuddin Hidayat and Mustolih Siradj, "Legal Arguments of Halal Product Guarantee (Argumentasi Hukum Jaminan Produk Halal),” Jurnal Bimas Islam 8, No. 1 (2015): 31-66.

${ }^{15}$ Mukidi, "Prosedur Pemberian Sertifikat Label Halal Terhadap Produk Makanan Di Restoran Hotel Syariah Untuk Mewujudkan Hak Kenyamanan Konsumen Muslim (Studi Di Kementerian Agama Provinsi Sumatera Utara)," dalam JURNAL HUKUM KAIDAH Media Komunikasi dan Informasi Hukum dan Masyarakat 19, no. 3 (2019).

${ }^{16}$ Ibid.

${ }^{17}$ Muhammad Tahir Azhari, Negara Hukum, Suatu Studi Tentang Prinsip-Prinsipnya Dilihat Dari Segi Hukum Islam, Implementasinya Pada Periode Negara Madinah Dan Masa Kini (Jakarta: Bulan Bintang, 1992).
} 
examine the halal assurance system of business actors; and h. report the results of the inspection and/or testing to the HIA".

Halal auditors also receive assistance from halal supervisors, as stipulated in Article 48 number 28 paragraph (1) of the Job Creation Law. "Halal supervisors as referred to in Article 24 letter c are tasked with: a. administering PPH within the company; $b$. decide remedial and preventive activities; c. planning PPH; and D. going with the HIA Halal Reviewer amid the examination".

The authority of the halal auditor is essentially to examine and/or test the halal of a product, in Article 48 number 31 paragraph (1) of the Job Creation Law it is regulated that "The inspection and/or testing of halal of the Product as referred to in Article 30 paragraph (1) is carried out by the Auditor Halal no later than 15 (fifteen) working days."

Business actors are required to provide information on their business locations to halal auditors, this is as stipulated in Article 48 number 31 paragraph (5) of the Job Creation Law, "In carrying out inspections at business locations as referred to in paragraph (2), Business Actors are required to provide information to Halal Auditors".

Ensuring legal certainty over protection for users of food products, both domestically produced and imported from other countries, the government stipulates the enactment of the JPH Law, with the intention that the sustainability of the halal production process is guaranteed by producers by implementing the Halal Assurance System, meaning that a producers must be able to guarantee that the food and/beverage products produced and/or traded must have a halal certificate. This means that it creates an obligation for every producer to carry out halal certification for their products, in order to create legal protection for users of these products. MUI and the government have their individual parts so there's no cover. Within the halal certification prepare, MUI through LPPOM MUI has the specialist to check and assess (halal review). ${ }^{18}$

The government through the Service of Religion is within the organization, supervision, and requirement segments. Within the another process, the assurance of the halal fatwa remains within the domain of the MUI, as some time recently. Through the HPA Law, the government features a part to require activity against the corporate division that commits infringement related to other items or nourishment. Prior to the enactment of the JPH Law, the authority of HPAA was carried out by LPPOM MUI, namely to carry out product halal inspections. At the beginning of its establishment in 1990, in carrying out its authority, this institution experienced many problems, where many thought that the halal certification process was too far-fetched and burdensome to the industry, even some companies questioned whether the certification carried out by LPPOM MUI could be accepted by the community. community, which at that time the public's understanding of the urgency of halal food with halal certification was still very early. This happened because of the lack of socialization regarding halal product certification as seen from the data obtained, namely 98\% stated that there was a need for socialization about halal products. In addition, there are still many companies who question the capacity of personal and institutional authorities to carry out audits, how is it possible for religious institutions such as the MUI to carry out audits within the industry with sophisticated technology as well. ${ }^{19}$

\footnotetext{
${ }^{18}$ Ralang Hartati, "Peran Negara Dalam Pelaksanaan Jaminan Produk Halal," in ADIL: Jurnal Hukum 10, No. 1 (2020).

${ }^{19}$ Ibid.
} 


\section{Comparative Halal Auditors between Brunei Darussalam and Indonesia}

In Brunei Darussalam, apart from an adequate quantity of halal auditors, there is also a code of ethics for halal auditors. Halal auditors are referred to as Trainee Auditors, namely someone who is in fact competent in examining Halal methods and necessities in certain nourishment preparing innovation or fields, but has not met the requirements based on the clause. the taking after: a) Qualified in a important logical or mechanical teach, with proportionate or identical academic/professional capabilities. b) Actually competent in a particular significant field. To do so, he or she must have a least of two (2) a long time of full-time work involvement in nourishment technology/food science, veterinary science or a important field. c) Have at slightest two (2) a long time of work encounter in halal assessment of commerce premises. d) Competent within the review framework where he is required to carry out an evaluation amid the review with the application of Halal methods and requirements. The enrolled preparing to be considered as Halal certification inspector has the taking after: a) Has satisfied the prerequisites of clause 3.1.1 (a) to (d) over; b) Has taken an interest in at slightest four (4) halal reviews (satisfactory and on-site) as a Preparing Member Evaluator under the administration of the Most reviewer; c) Be commonplace and learned in halal examining, directions, strategies. ${ }^{20}$

The Direction of the Devout Chamber in Brunei Darussalam, at point 4.2 clearly stipulates the code of morals for halal evaluators, as the rules contain that "Code of Morals An Evaluator might watch and comply with the taking after code of morals: a) To act professionally, precisely and in an fair-minded way; b) Not to speak to clashing or competing interface and to reveal to any client or employer any connections which will impact his/her judgment; c) Not to examine or unveil any data relating to an review unless required by law or authorized in composing by the auditee and the examining organization". ${ }^{21}$

Code of Ethics Auditors must watch and comply with the taking after code of morals: a) To act professionally, precisely and fairly; b) Not to speak to clashing or competing interface and to reveal to the client or boss any relationship that may impact his judgment; c) Not talk about or unveil any data related to the review unless required by law or authorized in composing by the auditee and the review organization. Reviewer Enrollment Each effective candidate will be given with a letter of arrangement and a certificate of enrollment as an evaluator for Halal compliance by the Majlis. Certification is substantial for a period of two (2) a long time. The list of reviewers will be overseen by the secretariat. Preparing may qualify to ended up an Inspector given the pertinent capabilities and involvement have been gotten (see Capability Criteria clause 3.2.1). In arrange to advance from Evaluator to Central Evaluator, the candidate must yield a completed review log (Reference section 2) appearing the review work perfom. The certification is valid for a period of two (2) years. The list of auditors will be managed by the secretariat. ${ }^{22}$

Still in Brunei Darussalam, Halal products are in the interest of all Muslim consumers, Halal Audit procedures should be common to all certification authorities to develop global standards. The protocols involved in the audit process should be universal, while local interpretations and 'fatwas' can still be included as long as the integrity of the Halal status is maintained and the interpretations are not for personal gain. Acceptance of a common review convention ought to be considered as a common dialect and beginning point for a

\footnotetext{
${ }^{20}$ The Religious Council and Brunei Darussalam, Guideline For Certification Halal Compliance Auditor, 2007.

${ }^{21}$ Ibid.

${ }^{22}$ Ibid.
} 
formal Muslim Standard for Halal exchange that's concurred upon by all parties. This will shape the premise of standard review hone, whereby inspectors will have, or may create, a common checklist and review arrange in their routine certification assignments. There's a enormous contrast between review and review. Whereas assessments approve certain Halal forms amid assessments, reviews hunt for prove of compliance working exterior of assessment times. This approach will decrease review time and maintain a strategic distance from pointless delays in issuing certificates, making them more 'industry friendly' to meet the ever-changing and expanding needs of the fabricating segment. In creating an 'implementation system' for a harmonized review framework, we are not rehashing Halal, but how to actualize it. ${ }^{23}$

Harmonization of halal reviews requires the advancement of particular review conventions to cover all angles of item fabricating. It isn't as it were a insignificant review of the materials to be consolidated into the fabricated item but moreover an emphasis on the complete taking care of prepare right from the point of obtainment of crude materials to the ultimate conveyance of the product to the proper customer. This can be the reason for contracting the proper inspectors with information of the sciences in nourishment generation as well as religion. This is often more critical in cutting edge nourishment generation including bundling, novel nourishments, Hereditarily Altered Life forms (GMOs) and recently created added substances for nourishment additives, emulsifiers, conditioners and stabilizers. With adequate understanding of the generation of nourishment and merchandise, we are ready to distinguish certain components all through the generation cycle to define a framework for the usage of the halal review convention. As it were at that point will the framework be able to make a mon. ${ }^{24}$

Compared to Indonesia, halal auditors are still quite minimal in various regions, plus there is no code of ethics for halal auditors as regulated in Brunei Darussalam, halal certification aims to provide legal certainty and legal protection for consumers, especially Muslim consumers. Based on the results of the study, legal protection for consumers against food products that are not certified halal can be concluded, that first, legal protection for Muslim consumers from food products that are not certified halal is regulated in the JPH Law. Halal certificates are mandatory (mandatory) so that food products that are not certified halal and labeled halal can no longer be circulated in Indonesia, whether produced domestically or from abroad. Second, commerce on-screen characters who have gotten halal certificates are required to incorporate halal names on item bundling, certain parts of the item and/or certain places on the item. Halal certificates are exceptionally imperative for Muslim shoppers because they involve religious principles and consumer rights. While there is a fact that not all food products are halal certified. Thus, efforts to provide adequate protection to the interests of consumers is an important matter and urgent to find a solution immediately. This problem arises because consumers are increasingly critical and need certainty about the food products they consume, both in terms of legality and good and halal quality. Moreover, with the opening of ASEAN free trade through the ASEAN Economic Community, processed food products from other countries will circulate freely in Indonesia. ${ }^{25}$

The guarantee for the execution of halal items points to supply consolation, security, security and certainty of the accessibility of halal items for the open in expending and

\footnotetext{
${ }^{23}$ Ibid.

${ }^{24}$ Ibid.

${ }^{25}$ Asri, "Perlindungan Hukum Bagi Konsumen Terhadap Produk Yang Tidak Bersetifikat Halal," Ius IV, no. 2 (2016): 2-21, accessed at http://jurnalius.ac.id/ojs/index.php/jurnalIUS/article/viewFile/316/pdf_2.
} 
using nourishment items. Usually imperative as portion of endeavors to secure shoppers from non-halal nourishment items. After the HPA Law was enacted, the authority to administer halal certification was no longer the authority of LPPOM but became the authority of HPAA. However, this authority is still carried out by LPPOM until the formation of BPJPH. This is stated in Article 59 of the HPA Law, namely "Before the Halal Product Guarantee Agency (BPJPH) was formed, the entire registration process and the renewal of halal certification were carried out according to the procedures that were in effect prior to the enactment of the HPA Law." The process of registration and renewal of halal certification is still carried out by LPPOM MUI. The role of LPPOM MUI then became one of the Halal Inspection Institutions (HIA) with the provision that it must comply with the provisions of Article 13 of the JPH Law no later than 2 years from the time HPAA was formed. In addition to the supervision aspect, the government must also conduct socialization and advocacy to business actors to carry out product labeling, mediate business actors and consumers, provide information on the meaning of halal, conduct socialization regarding HPA, supervise halal products in circulation and take care of halal certification if there are producers who use it. fake or invalid halal certificate. Likewise, business actors whose products use haram ingredients are required to include a haram label. The state is obliged to be present in providing guarantees and certainty of the halalness and prohibition of a product. ${ }^{26}$

The amount of food that is spread within the community without paying attention to the arrangements with respect to the incorporation of halal names is considered aggravating. Untrustworthy and/or deluding nourishment names and promotions on the improvement of human wellbeing. In the mean time, halal nourishment labeling, so distant, is as it were an commitment in the event that the producer/importer announces halal for Muslims. The name in question can be within the frame of data on the title of the products, measure, net, composition, rules of utilize, date of make, side impacts, title and address of the trade performing artist, halal data, as well as other data for utilize which agreeing to the arrangements must be made. Satjipto Rahardjo in KN Sofyan stated that in the context of law enforcement and protection of rights to certification and labeling of halal products, there are several significant things as follows: Law Enforcement System and Rights Protection. Non-legal factors, including culture, often make a difference in law enforcement between one community and another. Factors of the legal culture of society. Legal awareness, legal compliance and community behavior also determine the practice of protecting rights and law enforcement. If analyzed, there are at least three causes; 1) Muslim consumer beliefs regarding the obligation to consume halal products have not been followed by consistency in choosing standard halal certified products. As consumers, we often make price the determinant of choice; 2) Manufacturers often assume that the product does not use haram ingredients. This assumption is certainly true because there are many additives that may be haram; 3) The juridical aspect, halal certification in Indonesia is only an option, not yet a necessity, both for consumers and business actors or producers. ${ }^{27}$

Post-existence of the Employment Creation Law which provides convenience in the form of increasing the ease of making certification, accelerating halal certification services, facilitating certification financing for Micro-enterprises, structuring authority, and supporting the development of the halal ecosystem in Indonesia. This is where the state's

\footnotetext{
${ }^{26}$ Ibid.

${ }^{27} \mathrm{KN}$ Sofyan Hasan, "Pengawasan Dan Penegakan Hukum Terhadap Sertifikasi Dan Labelisasi Halal Produk Pangan," in Jurnal Hukum IUS QUIA IUSTUM 22, no. 2 (2015): 290-307.
} 
role manifests which continues to strive to supply welfare for its citizens through the arrangement of halal ensures for supporting food products. However, what is no less important are countries that need to watch the halal certification process strictly from halal certification to religious aspects in order to pursue "economical" profits. This supervision can be carried out in a preventive or repressive manner. The state is a public stakeholder who is in control to exercise control over the population and its territory. The existence of the state always likes the welfare of the people. The welfare in question is the public interest which is one of the goals of the state. Therefore, in utilizing it, every country must always prioritize the interests and/or welfare of the community, because historically the state exists because of the presence of the community in it.

Official rates Halal certification fees are regulated through a Regulation of the Minister of Finance. Official rates from the Government. The cost includes registration, LPH administration, auditor services, transportation, accommodation, laboratory checks, fatwa hearings, and certificate issuance. To keep transactions more transparent, payments are only made one door through BPJPH. To minimize flirting between business actors and LPH and auditors, fees are paid through the bank. ${ }^{28}$ Currently, the Government through the Ministry of Finance has issued regulations regarding tariffs or fees for halal certificates. This is stated in the Minister of Finance Regulation Number 57/PMK.05/2021 concerning Service Tariffs for the Public Service Agency for the Implementation of Halal Product Assurance at the Ministry of Religion. In the regulation, it is explained that the cost of halal product certification at BPJPH is around Rp. 300,000 to Rp. 5 million. ${ }^{29}$

Therefore, the existence of the Job Creation Law has made it easier for MSMEs with incomes below 1 (one) billion to receive subsidies from the government for halal certification. That way, the potential for halal certification registration from business actors must be accompanied by an optimal quantity of halal auditors.

Article 48 number 14 of the Job Creation amends Article 14 of the HPA Law so that the phrase becomes (1) Halal Auditors as referred to in Article 13 letter c are appointed and dismissed by HIA". (1) The appointment of Halal Auditor by HIA as referred to in paragraph (1) must meet the requirements.

Halal auditors are appointed and dismissed by HIA, this is as regulated in Article 14 paragraph (1) "Halal auditors as referred to in Article 13 letter c are appointed and dismissed by HIA". Article 14 paragraph (2) of the JPH Law "The appointment of a Halal Auditor by HIA as referred to in paragraph (1) must meet the following requirements: a. Indonesian citizens; b. are Muslim; c. have at least a bachelor's degree in food, chemistry, biochemistry, industrial engineering, biology, or pharmacy; d. understand and have broad insight regarding the halalness of products according to Islamic law; e. put the interests of the people above personal and/or group interests; and f. obtain a certificate from the MUI.

As for the requirements to become a Halal Auditor in Article 18 of the current Job Creation Law, it reads: a. Indonesian citizens; b. are Muslim; c. have a minimum education of bachelor's degree 1 (one) in the fields of food biochemistry, industrial engineering, culinary management, agriculture; d. understand and have broad insight regarding the halalness of products according to Islamic law; and e. put the interests of the people above the personal interests of the group. In this case, it is different from the HPA Law which

\footnotetext{
${ }^{28}$ Farid Wajdi, Diana Susanti, Kebijakan Hukum Produk Halal, (Jakarta: Sinar Grafika), p. 10

${ }^{29}$ Berikut Biaya Sertifikat Halal dan Cara Mendapatkannya, accessed at https://money.kompas.com/read/2021/06/28/132137026/berikut-biaya-sertifikat-halal-dan-caramendapatkannya?page $=$ all
} 
criteria for halal auditors must obtain a certificate from the MUI. Currently, only the authority of HIA.

In Indonesia, the protection of halal products (food) is the main prerequisite that must be fulfilled by business actors so that their products can be traded because the distributed food will be absorbed (consumed) by the market where the majority of consumers are Muslim. As is known, the product halal factor (not limited to food products) is an important part of the life of a Muslim community that must be obeyed because it is a religious command. Therefore, information about the content of food products as well as information on product halalness is something that should not be ignored by business actors so that they are worthy of distribution to the public. ${ }^{30} \mathrm{HIA}$ has the authority to audit and examine products submitted by business actors, report the results of the inspection to HPAA. $^{31}$ In 2020, after the Job Creation Law, MSMEs also need to have their halal certification registered, so the need for halal auditors also needs to be increased. Because, before MSME products are recommended to be made halal certified, Indonesia still lacks halal auditors, plus currently MSME products also need to have halal certification.

\section{CONCLUSION}

Halal auditor in charge of checking the product halal. The process to become a halal auditor has so far been carried out centrally in Jakarta through training, during the COVID19 pandemic it was carried out online, but in essence it is still optimizing the quantity of halal auditors so that they are more optimal in halal inspection so that there is an increase in halal product guarantees in Indonesia. Reflecting on Brunei Darussalam, apart from an adequate quantity of halal auditors, there is also a code of ethics for trainee auditors (halal auditors), so Indonesia needs to optimize the number of halal auditors and also have a code of ethics for halal auditors.

\section{REFERENCES}

Angriyani, Ari Mariyana, And Elisatris Gultom. (2021). Peran Negara Dalam Memberikan Perlindungan Pada Konsumen Atas Penggunaan Produk Pangan Tidak Berlabel Halal Berdasarkan Undang-Undang Nomor 33 Tahun 2014 Tentang Jaminan Produk Halal. dalam Widya Yuridika: Jurnal Hukum, 4(1)

Asri. (2016). Perlindungan Hukum Bagi Konsumen Terhadap Produk Yang Tidak Bersetifikat Halal. Ius Iv, No. 2 (2016): 2-21.

Azhari, Muhammad Tahir. (19922). Negara Hukum, Suatu Studi Tentang PrinsipPrinsipnya Dilihat Dari Segi Hukum Islam, Implementasinya Pada Periode Negara Madinah Dan Masa Kini. Jakarta: Bulan Bintang

Berikut Biaya Sertifikat Halal dan Cara Mendapatkannya, accessed at https://money.kompas.com/read/2021/06/28/132137026/berikut-biaya-sertifikat-halaldan-cara-mendapatkannya?page=all

BPJPH Tegaskan Fatwa Penetapan Halal Tetap di MUI, accessed at https://www.halalmui.org/ mui14/main/detail/bpjph-tegaskan-fatwa-penetapan-halaltetap-di-mui

\footnotetext{
${ }^{30}$ Ari Mariyana Angriyani and Elisatris Gultom, "Peran Negara Dalam Memberikan Perlindungan Pada Konsumen Atas Penggunaan Produk Pangan Tidak Berlabel Halal Berdasarkan Undang-Undang Nomor 33 Tahun 2014 Tentang Jaminan Produk Halal," in Widya Yuridika: Jurnal Hukum, 4, no. 1 (2021).

${ }^{31}$ Farid Wajdi, “Implikasi Undang-Undang Jaminan Produk Halal,” Republika (2017).
} 
Charity, May Lim. (2017). Jaminan Produk Halal Di Indonesia.” Jurnal Legislasi Indonesia $14(1)$

Council. (2007). The Religious, And Brunei Darussalam. Guideline For Certification Halal Compliance Auditor

Dewi, Diana Candra. (2007). Rahasia Dibalik Makanan Yang Haram. Malang: UIN

Hartati, Ralang. (2020). Peran Negara Dalam Pelaksanaan Jaminan Produk Halal. Adil: Jurnal Hukum 10, No. 1 (2020).

Hasan, Kn Sofyan. (2015). Pengawasan Dan Penegakan Hukum Terhadap Sertifikasi Dan Labelisasi Halal Produk Pangan in Jurnal Hukum Ius Quia Iustum 22(2)

Hidayat, Asep Syarifuddin, And Mustolih Siradj. (2015). Legal Arguments Of Halal Product Guarantee (Argumentasi Hukum Jaminan Produk Halal).” in Jurnal Bimas Islam 8(1)

Hidayatullah, Muhammad Syarif. (2020). Sertifikasi Dan Labelisasi Halal Pada Makanan Dalam Perspektif Hukum Islam (Perspektif Ayat Ahkam)." in Yudisia: Jurnal Pemikiran Hukum Dan Hukum Islam 11(2)

Irawan, Fabbiola. (2019). Polemik Sertifikasi Halal, Ini Sederet Masalah Di Baliknya." accessed at https://Economy.Okezone.Com/Read/2019/12/18/320/2143594/PolemikSertifikasi-Halal-Ini-Sederet-Masalah-Di-Baliknya?Page $=2$.

Journal, The Halal. (2004). Harmonising Halal: The Importance Of Halal Auditing." melalui https://Thehalaljournal.Wordpress.Com/2004/08/31/Harmonising-Halal-TheImportance-Of-Halal-Auditing

Marzuki, Peter Mahmud. (2011). Penelitian Hukum. Jakarta: Kencana

MUI, LPPOM. Menjadi Auditor Dan Penyelia Halal Tersertifikasi Saat Ini Mudah.” accessed at https://www.Halalmui.Org/Mui14/Main/Detail/Menjadi-Auditor-DanPenyelia-Halal-Tersertifikasi-Saat-Ini-Mudah.

- Sertifikasi Auditor Halal, Belum Ada Pendaftar Dari Luar." accessed at https://www.Halalmui.Org/Mui14/Main/Detail/Sertifikasi-Auditor-Halal-Belum-AdaPendaftar-Dari-Luar.

Mukidi. (2019). Prosedur Pemberian Sertifikat Label Halal Terhadap Produk Makanan Di Restoran Hotel Syariah Untuk Mewujudkan Hak Kenyamanan Konsumen Muslim (Studi Di Kementerian Agama Provinsi Sumatera Utara)." Jurnal Hukum Kaidah Media Komunikasi Dan Informasi Hukum Dan Masyarakat 19(3)

Muslimah, Siti. (2012). Label Halal Pada Produk Pangan Kemasan Dalam Perspektif Perlindungan Konsumen Muslim." in Yustisia 1(1)

Puspaningtyas, Lida. Dewan Pakar Mes Sebut Kendala Jaminan Produk Halal. accessed at https://Www.Republika.Co.Id/Berita/Qyzo2f370/Dewan-Pakar-Mes-Sebut-KendalaJaminan-Produk-Halal.

Republika. BPJPH Keluhkan Tarif Sertifikasi Auditor Halal. accessed at https://www.Republika.Id/Posts/9340/Bpjph-Keluhkan-Tarif-Sertifikasi-AuditorHalal\%C2\% A0.

Soekanto, Soerjono. (2012). Pengantar Penelitian Hukum. Jakarta: UI Press

The Religious Council and Brunei Darussalam. (2007). Guideline For Certification Halal Compliance Auditor

Wajdi, Farid. (2017). Implikasi Undang-Undang Jaminan Produk Halal. Republika Grafika) Diana Susanti, Kebijakan Hukum Produk Halal di Indonesia, (Jakarta: Sinar _. (2019).Jaminan Produk Halal Di Indonesia. Jakarta: PT. Rajagrafindo Persada 